\title{
Vulvar Seborrheic Keratosis
}

National Cancer Institute

\section{Source}

National Cancer Institute. Vulvar Seborrheic Keratosis. NCI Thesaurus. Code C6375.

A benign squamous neoplasm that arises from the vulva. It is characterized by the

proliferation of the basal cells in the squamous epithelium, acanthosis, hyperkeratosis, and cysts formation. 